\title{
Agronomic and Economic Responses of Spring Wheat to Management of Fusarium Head Blight
}

\author{
C. R. Hollingsworth and C. D. Motteberg, University of Minnesota, Northwest Research and Outreach Center and \\ Department of Plant Pathology, and J. V. Wiersma, University of Minnesota, Northwest Research and Outreach \\ Center, Crookston, MN 56716; and L. M. Atkinson, University of North Dakota, Department of Earth System Sci- \\ ence and Policy, Northern Great Plains Center for People \& Environment, Grand Forks, ND 58202-9011
}

\begin{abstract}
Hollingsworth, C. R., Motteberg, C. D., Wiersma, J. V., and Atkinson, L. M. 2008. Agronomic and economic responses of spring wheat to management of Fusarium head blight. Plant Dis. 92:1339-1348.

Spring wheat (Triticum aestivum) crop losses in the Red River Valley of Minnesota and North Dakota caused by Fusarium head blight (FHB) epidemics incited by Fusarium graminearum are common. Fungicide application is often recommended when environments promote disease development but benefits have not been fully evaluated when environment, cultivar resistance, and economic outcome are considered. Agronomic and economic characters were determined for cultivars with various resistance levels when treated with no fungicide; propiconazole at $63 \mathrm{~g}$ active ingredient (a.i.)/ha applied at Feekes growth stage (FGS) 2, tebuconazole at $126 \mathrm{~g}$ a.i./ha applied at FGS 10.51, or propiconazole at $63 \mathrm{~g}$ a.i./ha applied at FGS 2 followed by tebuconazole at $126 \mathrm{~g}$ a.i./ha applied at FGS 10.51. Revenue returned from FHB moderately susceptible (MS) cultivars was $8 \%$ greater than moderately resistant (MR) cultivars in low-disease environs but differences were not significant when disease was moderate. Deoxynivalenol accumulation in grain of MS and MR cultivars was unchanged by fungicide treatment. MS cultivars were economically more adventitious to grow than MR cultivars in both disease environments.
\end{abstract}

Additional keywords: disease management

During 1997, Fusarium head blight (FHB; caused by Fusarium graminearum Schwabe, teleomorph Gibberella zeae (Schwein) Petch) was described by smallgrain cereal researchers as a reemerging disease in Upper Midwest states $(29,47,48)$ due to widespread and repeated epidemics $(46,50)$. These epidemics were responsible for changing the sociologic and economic norms of agricultural communities in the region $(2,28,37,53)$. Crop losses of hard red spring wheat (Triticum aestivum L.) and spring barley (Hordeum vulgare L.) have occurred on a nearly annual basis since the early 1990s, resulting in severe financial difficulties for farmers that have, in many cases, led to bankruptcy and foreclosure $(28,53)$. In response, many producers have modified their crop production strategies to limit disease development, thereby managing crop losses. Overall, weather conditions have remained favorable for the disease during critical host infection periods which have, in turn, promoted disease development.

Corresponding author: C. R. Hollingsworth

E-mail: holli030@umn.edu

Accepted for publication 22 May 2008.

doi:10.1094/PDIS-92-9-1339

(C) 2008 The American Phytopathological Society
FHB epidemics can reduce small-grain cereal yield and kernel quality. Spikelet sterility can result when plant tissues are infected by $F$. graminearum early in a susceptible growth stage (50). The pathogen produces mycotoxins, termed trichothecenes, in grain $(4,9,45)$. One such widely known toxin, deoxynivalenol (synonyms: DON, vomitoxin), presents a worldwide human and livestock health issue when ingested $(6,13,45)$. Consuming DONcontaminated grain can damage cells in the gastrointestinal tract and alter neurochemicals in the brain, resulting in vomiting and anorexia, also described as feed refusal in the case of livestock $(7,36,45,51)$.

If $F$. graminearum infection occurs after grain begins to fill, severely diseased kernels turn white to pinkish in color and are small and shriveled $(1,25)$. During 2003, grain produced in the southeastern United States appeared sound, but FHB-diseased kernels contained elevated concentrations of DON (8).

Since the early 1990s, FHB has been one of the greatest impediments to economic small-grain production in the Red River Valley. Minnesota grain elevators have discounted wheat grain delivered by producers when DON levels are $\geq 2 \mathrm{ppm}$. Elevators have the option of refusing deliveries to manage merchandiser risks if grain does not meet quality characteristics for which grain is contracted (20). Current
U.S. Food and Drug Administration guidelines advise toxin concentrations should not exceed (i) $1 \mathrm{ppm}$ in finished wheat products used for food (flour, germ, or bran); (ii) $5 \mathrm{ppm}$ in feed for swine, with a $20 \%$ limit for total feed ration; and (iii) 10 ppm in feed for cattle at least 4 months old and chickens, with a $50 \%$ limit for total feed ration (3).

The small-grain research community is under pressure from public and private stakeholders to resolve the food safety issue quickly and completely. To remain in business, millers require wholesome, locally produced wheat grain while producers need wheat cultivars that can produce large yields of high-quality grain. Plant pathology extension specialists and others continue to promote an integrated disease management approach based on sound science. Recommendations for spring wheat production include growing cultivars with FHB resistance, rotating crops, managing infested crop residues, utilizing online FHB epidemic risk forecasting systems to schedule a timely application of fungicide, and following soil fertility guidelines $(5,10-12,17,31,39,50)$.

Most agriculture professionals and many small-grain producers in the Red River Valley of Minnesota and North Dakota are well acquainted with these recommendations, yet they continue to "farm for yield," putting much less emphasis on grain quality issues caused by FHB. Many producers select spring wheat cultivars based on yield potentials, while kernel quality characteristics such as protein, test weight, and DON accumulation are secondary considerations. Producers regularly plant two or more cultivars with varying levels of resistance to manage the risk for loss caused by disease. They perceive economic returns received from higher yields with lowerquality grain to be economically more advantageous compared with lower yields of higher-quality grain. This supposition is widely accepted in the agricultural community and scientific information on the topic is scarce. Researchers in Turkey have identified a positive correlation between high-yielding, lower-kernel-quality cultivars with greater economic benefits (38). According to Özberk et al. (38), the “(m)arket prices, offered for good quality grain were not sufficient to change the order of profitability" from growing 
higher-yielding cultivars which produce lower-quality grain. This phenomenon can be better understood by identifying the economic climate in which wheat grain is marketed in the United States.

The U.S. wheat grain market is organized into grain classes (hard red spring, durum, hard red winter, soft red winter, hard white, soft white, unclassed, and mixed wheat) and grade numbers (grades $1,2,3,4,5$, and sample). Grades of wheat are established by determining bushel test weights (pounds per Winchester bushel [lb/bu]), percent kernel defects (damaged or shrunken kernels or other classes of wheat kernels present), and presence of foreign contaminates (castor beans, glass, stones, insect-damaged kernels, and so on). Grade U.S. No. 1 grain represents superior quality wheat having a minimum test weight of $58 \mathrm{lb} / \mathrm{bu}$ with a maximum kernel defect limit of $3 \%$ and damaged-kernel content of $2 \%$. Grades U.S. No. 2 to No. 5 are based on a sliding scale, with grade U.S. No. 5 grain having more quality issues compared with grades 1 through 4 . The market pays growers a larger cash base price for grain in grade U.S. No. 1 as opposed to No. 2, and so on. As the grade number indicator increases to 5 , the cash base price received by a producer decreases accordingly. Actual cash base prices fluctuate with the grain market and can vary substantially over time.

Cultivar and fungicide treatment response differences depend on disease incidence and severity. Because some environments are more favorable for disease development than others, trials are often done at several locations and across years to characterize treatment differences across environments (year $\times$ location effects). Previous research reports differences between fungicide treatments in relation to disease severity $(21,40,42)$. However, few reports include cultivar response to fungicide application across years and locations in terms of FHB symptom expression, grain yield and quality, and economic outcome. The objective of this study was to evaluate the effects that commonly recommended integrated disease management strategies had on controlling yield and quality losses caused by FHB in environments with naturally occurring disease pressures. Specifically, we were interested in determining whether (i) cultivars rated as moderately resistant (MR) or moderately susceptible (MS) to FHB benefit differently in terms of revenue return from treatment (fungicide application versus no fungicide) when environmental conditions promote or do not promote FHB development, and (ii) there are significant increases in grain yield and quality due to fungicide treatment of cultivars rated as MR or MS to FHB in environments described above.

\section{MATERIALS AND METHODS}

Field trials. Because our primary interest was cultivar response to FHB and grain quality degradation caused by FHB, rather than leaf diseases, we tested and compared cultivars known for MR or MS responses to FHB. During 2004 and 2005, five hard red spring wheat cultivars were tested within a total of eight commercial fields located in the Red River Valley of Minnesota. Locations were environmentally diverse yet were known for their potential for high disease severity if an FHB epidemic occurred in the Red River Valley. Cultivars were selected based on published resistance ratings for FHB (2) and represented MR or MS responses to the disease. Cultivars had different resistance response combinations for leaf spot and rust diseases (Table 1). During 2004, trials were planted on 16, 19, 22, and 26 April, and 3 May near Perley, Rothsay, Oklee, Hallock, and Strathcona, MN, respectively. During 2005, trials were planted on 18,20, 21, 22, and 26 April near Perley, Fergus Falls, Hallock, Oklee, and Strathcona, MN, respectively. Data from the 2005 Hallock and Strathcona sites are not reported due to severe weather and flooding at those sites. Plots were seeded at approximately 3.1 million viable seed/ha, and treatments were arranged in a randomized complete block design with four replications. Plots were planted $8.2 \mathrm{~m}$ long by $1.5 \mathrm{~m}$ wide with 10 rows spaced $15.2 \mathrm{~cm}$ apart and cultivated to a finished length of $7.6 \mathrm{~m}$ at approximately the Feekes growth stage (FGS) 2. Each test location was maintained according to conventional tillage management production recommendations for the area (52). Trials were exposed to naturally occurring inoculum levels and disease pressures. Amount of in-field crop residue varied from site to site. Tests were planted into soybean (2004 Hallock, 2004 Strathcona, 2004 and 2005 Oklee, 2004 Perley, and 2005 Fergus Falls), barley (2004 Rothsay), or sunflower (2005 Perley) crop residues according to the rotation schedule of each grower-cooperator.

Fungicide treatments. A common fungicide strategy meant to suppress FHB symptoms was tested. The treatment included an application of fungicide at FGS 10.51. If this treatment paired with the nonfungicide treatment was used exclusively, it is possible that confounding effects from nontreated, early-season leaf disease injury might influence our results. For completeness, two additional foliar disease-management strategies were included to determine the contributory effects of foliar disease. One strategy included a fungicide application at FGS 2 to manage foliar disease exclusive of FHB suppression and the second strategy included an application of fungicide at FGS 2 followed by a second at FGS 10.51. This was done to determine whether two applications of fungicide interact to provide an increased level of protection against diseases compared with a single fungicide application at either the FGS 2 or FGS 10.51 timing. In total, four commonly practiced foliar or FHB disease-management strategies were tested at each experiment location. Strategies included (i) a nontreated control, (ii) propiconazole (Tilt 3.6 EC; Syngenta, Raleigh, NC) at $63 \mathrm{~g}$ active ingredient (a.i.)/ha applied at the four- to five-leaf crop growth stage (FGS 2), (iii) tebuconazole (Folicur 3.6 F; Bayer CropScience, Research Triangle Park, NC) at $126 \mathrm{~g}$ a.i./ha applied at the early-anthesis crop growth stage (FGS 10.51), and (iv) propiconazole at $63 \mathrm{~g}$ a.i./ha applied at FGS 2 followed by tebuconazole at $126 \mathrm{~g}$ a.i./ha applied at FGS 10.51 (FGS 2 + FGS 10.51). All treatments, except the nontreated control, included $0.125 \%$ Induce (Helena Chemical Co., Collierville, TN), a nonionic surfactant. Fungicide treatments at FGS 2 were applied with TeeJet Technologies XR 8002 flat-fan nozzles (Wheaton, IL) spaced $51 \mathrm{~cm}$ apart and positioned vertically to spray in a downward pattern. The FGS 10.51 applica-

Table 1. Fusarium head blight (FHB) and foliar disease response ratings for five hard red spring wheat cultivars grown in Minnesota

\begin{tabular}{|c|c|c|c|c|c|c|}
\hline \multirow[b]{2}{*}{ Cultivar } & \multirow[b]{2}{*}{ Origin } & \multirow[b]{2}{*}{ Release date } & \multicolumn{4}{|c|}{ Disease resistance ratings $^{\mathrm{a}}$} \\
\hline & & & FHB & Group $^{b}$ & Leaf spots ${ }^{\mathrm{c}}$ & Leaf rust ${ }^{\mathrm{d}}$ \\
\hline Alsen & North Dakota State University & 2000 & 4 & MR & 6 & 3 \\
\hline Walworth & South Dakota State University & 2001 & 5 & MR & 8 & 6 \\
\hline Knudson & AgriPro-COKER & 2001 & 6 & MR & 3 & 1 \\
\hline Reeder & North Dakota State University & 1999 & 7 & MS & 4 & 8 \\
\hline Oxen & South Dakota State University & 1996 & 8 & MS & 7 & 7 \\
\hline
\end{tabular}

a Disease resistance scale from 1 to 9 , where 1 is most resistant and 9 is most susceptible (2).

${ }^{\mathrm{b}}$ Qualitative FHB disease resistance designations, where MR is moderately resistant and MS is moderately susceptible.

${ }^{c}$ Disease response ratings, including injury by tan spot, caused by Pyrenophora tritici-repentis (Died.) Drechsler; Stagonospora leaf blotch, caused by Stagonospora nodorum (Berk.) Castell. \& Germano; and Septoria tritici blotch, caused by Septoria tritici Desm. (2).

${ }^{\mathrm{d}}$ Disease response ratings for leaf rust, Puccinia triticina (Roberge ex Desmaz. f. sp. tritici) (2). 
tions were made with TeeJet Technologies XR 8001 VS flat-fan nozzles spaced $51 \mathrm{~cm}$ apart and angled to spray forward and backward to the direction of travel. All fungicide applications were made using a $\mathrm{CO}_{2}$ backpack applicator with a delivery pressure of $242 \mathrm{kPa}$ and an application rate of 187 liters/ha.

Data collection. Percent flag leaf area with lesions was recorded from eight arbitrarily selected flag leaves per plot when plants were at the soft dough stage (approximately FGS 11.2). Leaf disease ratings were assessed once during 2004 on 28, 29, and 30 July and 3 and 5 August at the Perley, Oklee, Rothsay, Hallock, and Strathcona sites, respectively; and once during 2005 on 11, 14, and 22 July at the Fergus Falls, Perley, and Oklee sites, respectively. Disease ratings from each symptomatic flag leaf included all common fungal leaf-spotting diseases, including lesions of tan spot caused by Pyrenophora tritici-repentis, Stagonospora leaf blotch caused by Stagonospora nodorum, and Septoria tritici blotch caused by Septoria tritici. Ratings also included percent leaf area injured by emerged pustules from leaf rust caused by Puccinia triticina and stripe rust caused by $P$. striiformis $\mathrm{f}$. sp. tritici.

Fifty spikes were arbitrarily selected from each plot at approximately FGS 11.3. Spikes were placed into labeled, selfclosing plastic bags and frozen at approximately $-23^{\circ} \mathrm{C}$ until $\mathrm{FHB}$ symptoms were rated less than 6 weeks later. FHB severity assessments were made according to a published visual estimation aid (49), and incidence (percent of spikes with at least one symptomatic spikelet) was recorded from the collected spikes. Severity and incidence data were used to determine percent $\mathrm{FHB}$ index/plot [FHB index = (FHB severity $\times$ FHB incidence) $/ 100]$.

During 2004, Perley, Rothsay, Oklee, Hallock, and Strathcona tests were harvested on 18 and 20 August and 1, 14, and 18 September, respectively, using a smallplot combine. During 2005, Oklee, Perley, and Fergus Falls tests were harvested on 15, 13, and 10 August, respectively. Grain was cleaned using a Clipper Eclipse seed and grain cleaner (Bluffton, IN) and harvest weights were determined. Percent grain protein and moisture were measured using an Infratec grain analyzer (Eden Prairie, $\mathrm{MN}$ ) and yield and test weight data were adjusted to $13.5 \%$ moisture. Grain subsamples of approximately $75 \mathrm{~g}$ were assessed for percent visually scabby kernels (VSK) using a set of grain standards (22). DON accumulation in grain was determined by the University of Minnesota Mycotoxin Laboratory using batch gas chromatography-mass spectrometry from grain subsamples of approximately $5 \mathrm{~g}$ (35).

Revenue analysis. During 2004 and 2005, grain grades were determined from test weight and VSK means. Grain prices were calculated from cash price quotes obtained locally on 11 November of each year (2004: \$3.63/bu [\$127.92/liter] and 2005: $\$ 3.76 / \mathrm{bu} \quad[\$ 132.50 /$ liter $]$ ). After grades were assigned, discounts and premiums were applied, if applicable.

During 2004, grades U.S. No. 2, 3, and 4 returned $0.20,0.40$, and $\$ 0.70 / \mathrm{bu}$ less, respectively, than U.S. No. 1. There were no foreign contaminates after cleaning, and grain had acceptably low DON levels; therefore, discounts were not incurred. Discounts for percent grain protein were assessed at less than the $14 \%$ base value. Grain was devalued by $\$ 0.07 / \mathrm{bu}$ (\$2.47/liter) at $0.2 \%$ intervals (e.g., $13.8 \%$ $=-\$ 0.07 / \mathrm{bu}, 13.6 \%=-\$ 0.14 / \mathrm{bu}$, and so on), whereas a $\$ 0.06 /$ bu $(\$ 2.11 /$ liter $)$ premium was added at $0.2 \%$ intervals greater than the base value $(14.2 \%=+\$ 0.06 / \mathrm{bu}$, $14.4 \%=+\$ 0.12 / \mathrm{bu}$, and so on).

During 2005, grades U.S. No. 2, 3, and 4 returned $0.20,0.30$, and $\$ 0.50 / \mathrm{bu}$ less, respectively, than U.S. No.1. Again, there were no foreign contaminates in grain samples; therefore, contaminate-based discounts were not incurred. Grain was discounted for DON accumulation because of a widespread FHB epidemic. Discounts were applied at $-\$ 0.03 / \mathrm{bu}$ increments for every $0.5 \mathrm{ppm}$ rise in DON content beginning at $2.1 \mathrm{ppm}$ (2.1 to $2.5 \mathrm{ppm}=$ $-\$ 0.03 / \mathrm{bu}, 2.6$ to $3.0 \mathrm{ppm}=-\$ 0.06 / \mathrm{bu}$, and so on). Grain with protein below the $14 \%$ base value was devalued by $\$ 0.03 / \mathrm{bu}$ (\$1.06/liter) at $0.2 \%$ intervals (e.g., $13.8 \%$ $=-\$ 0.03 / \mathrm{bu}, 13.6 \%=-\$ 0.06 / \mathrm{bu}$, and so on), while a $\$ 0.02 / \mathrm{bu}(\$ 0.70 /$ liter $)$ premium was added at $0.2 \%$ intervals greater than the base value $(14.2 \%=+\$ 0.02 / \mathrm{bu}$, $14.4 \%=+\$ 0.04 / \mathrm{bu}$, and so on).

After the gross estimated proceeds per hectare were determined, fungicide and application costs were subtracted to adjust treatment data across disease-management strategies. Fungicide application costs were estimated at \$4.50/A (\$11.12/ha) and \$5.00/A (\$12.35/ha) during 2004 and 2005, respectively. Local cost estimates for fungicides were obtained from a competitively priced Crookston, $\mathrm{MN}$ area farmer cooperative at $\$ 5.00 / \mathrm{A}(\$ 12.35 / \mathrm{ha})$ for propiconazole and \$9.00/A (\$22.23/ha) for tebuconazole.

An application cost was not included in the analysis for the FGS 2 fungicide timing application, because many producers tank mix fungicide with one or more herbicides. Herbicide application is done on a routine basis regardless of whether a fungicide application is made.

During 2004 and 2005, total estimated costs of fungicide treatments were (i) $\$ 0.00 / \mathrm{A}(\$ 0.00 / \mathrm{ha})$ for the nontreated control, (ii) $\$ 5.00 / \mathrm{A}(\$ 12.35 / \mathrm{ha})$ for propiconazole at FGS 2, (iii) \$14.00/A (\$34.58/ha) for tebuconazole at FGS 10.51 , and (iv) $\$ 19.00 / \mathrm{A}$ (\$46.93/ha) for propiconazole at FGS 2 followed by tebuconazole at FGS 10.51 .
Economic returns discussed here are specific to differences caused by disease management alone and do not include other associated crop production input costs regularly incurred by producers such as fertilizer, fuel, seed, herbicide application, labor, equipment and facilities maintenance, crop insurance, and so on.

Data analysis. Experiments at each test location were arranged in a randomized complete block design with four replications. Test locations covering a wide range of longitude and a lesser range of latitude were chosen at random from a potentially larger pool of sites. For this reason, location was considered to be a random factor, as was year (24). Retrospectively, analyses using year $\times$ location combinations were used to determine treatment responses from subpopulations (23), termed environments, which were either more or less favorable for FHB development. Cultivar and fungicide treatments were considered fixed effects, whereas block (location), years, and all interaction terms in the model were considered random factors, with the exception of the cultivar $\times$ fungicide interaction. Thus, in accordance with Littell et al. (24), best linear unbiased estimate (BLUE) values were calculated for cultivar, fungicide, and the cultivar $\times$ fungicide interaction. Likewise, best linear unbiased prediction (BLUP) values were calculated for the remaining factors and interactions $(24,44)$. Many BLUPs pertained to location-specific effects and did not add significantly to the content of this article. Consequently, they are not reported here.

A series of models was run using PROC MIXED (SAS Institute, Inc., Cary, NC) to analyze the mixed nature of the study. A model using PROC MIXED METHOD $=$ TYPE 3 was run to assess the significance of random effects and interactions involving random effects in the model. This preliminary investigation indicated the magnitude and direction of the covariance parameters and of the potential importance of each factor and its associated interaction in the analysis. Although not reported here, the model indicated what results could be expected when BLUEs and BLUPs were calculated with PROC MIXED Method $=$ REML regarding the importance of specific factors and interactions. Other models using PROC MIXED Method=REML were compared for improvements in model-fitting criteria when (i) residual variances were assumed to be homogeneous, (ii) separate residual variances were fit for each environment, and (iii) separate residual variances were fit for groups of environments or cultivars. This procedure involved using the REPEATED/GROUP option of PROC MIXED and the log likelihood ratio test (SAS Institute Inc.). The selected model fit separate residual variances for each environment. Three parameters had random covariance parameters values that were either near zero or nega- 
tive (FHB incidence, environment $\times$ cultivar $\times$ fungicide; test weight, environment $\times$ fungicide; test weight, block(environment); VSK, environment $\times$ fungicide, and VSK, block(environment), which were thus removed from the model. Consequently, not all random effects were included in our model for each parameter. The SAS code from which each model was derived is shown below, where: $\mathrm{C}=$ cultivar, $\mathrm{F}=$ fungicide, $\mathrm{ENV}=$ environment, and BLK $=$ block

$\begin{array}{ll}\mathrm{Y}=\mathrm{C} \times \mathrm{F} / \text { Method }=\mathrm{REML} \text { ddfm }=\mathrm{kr} \\ \text { Random } & \mathrm{ENV} \\ & \mathrm{BLK}(\mathrm{ENV}) \\ & \mathrm{ENV} \times \mathrm{C} \\ & \mathrm{ENV} \times \mathrm{F} \\ & \mathrm{ENV} \times \mathrm{C} \times \mathrm{F} .\end{array}$

The leaf disease variance residual model was fit separately and transformed using the LOG10 function. Test weight residuals best fit the two-environment group model where environments 1 through 5 and 6 through 8 were combined. These data were transformed using the square root function. Data were further analyzed using BLUEs and BLUPs to examine interactions. Environments were characterized as having low FHB (environment 1 [ENV1], five locations in 2004) or moderate FHB (environment 2 [ENV2], three locations in 2005:). Mean estimate, BLUE, and BLUP values were used to determine the magnitude and direction of significant differences. Cultivars were grouped into one of two FHB resistance groups (MS or MR) as well as analyzed individually.

\section{RESULTS}

Disease development. Leaf-spotting disease-severity ratings were low but differences between cultivars, fungicide treatments, and two interactions were significant (Table 2). Leaf disease-rating means were not different between environments having low (ENV1) or moderate (ENV2) FHB (Table 3). Moreover, differences were not significant between cultivars (Table 3). Significant effects were identified within fungicide treatment. Leaf disease injury was not different when plants were treated with fungicide compared to the nontreated control. When fungicide was applied at FGS 2 and again at FGS 10.51, leaf disease severity was $21.3 \%$ less than the single fungicide application made at FGS 2 (Table 3).

BLUE analyses identified significant effects within the cultivar $\times$ fungicide interaction. When Alsen and Walworth were contrasted to Knudson within the nonfungicide control treatment, the latter had $25 \%$ less leaf area injured by disease (Table 4 ). Disease severity decreased by $18 \%$ for Oxen and Reeder and by $11 \%$ for Knudson when cultivars were treated with fungicide compared with the nontreated fungicide control (Table 4).

Five of eight sources of variation from the PROC MIXED analyses were significant for FHB incidence, severity, and index (Table 2). Prevalence of FHB symptoms were significantly less in ENV1 than in ENV2 (Table 3). In ENV1, FHB ratings were $36.9 \%$ less for incidence, $30.1 \%$ less for severity, and $61.4 \%$ less for index than in ENV2 (Table 3). Significant differences existed among cultivars as well. Grouped cultivars with moderate resistance to FHB (Alsen, Walworth, and Knudson) had fewer symptoms for FHB incidence, severity, and index than grouped cultivars with moderate susceptibility to the disease (Reeder and Oxen; Table 3). MR cultivars were largely comparable. Alsen and Walworth showed $28.6 \%$ greater FHB incidence symptoms than Knudson while FHB severity and FHB index were not significantly different. MS cultivars Oxen and Reeder were not significant for FHB severity and index but Oxen exhibited $11.5 \%$ more incidence symptoms than Reeder.

Fungicide treatment results differed for FHB incidence and FHB index but not FHB severity (Table 3). Fungicide application resulted in less FHB incidence and lower FHB indices compared with the nonfungicide control. The FGS $2+$ FGS 10.51 treatment resulted in $11.8 \%$ fewer FHB incidence symptoms and 14.9\% lower FHB index means compared with the FGS 2 treatment (Table 3).

Significant interaction effects in FHB incidence, severity, and index were otherwise hidden by PROC MIXED METHOD $=$ TYPE 3 analyses within cultivar $\times$ fungicide, environment $\times$ cultivar, and environment $\times$ fungicide (Tables 4-6).

When MR and MS cultivars were analyzed within the nonfungicide control, the latter had $21.9 \%$ greater FHB incidence, $22.0 \%$ greater FHB severity, and $41.5 \%$ greater FHB index means (Table 4). When the same comparison was made using fungicide application treatment means, MS cultivars had $25.1 \%$ greater FHB incidence, $23.4 \%$ greater FHB severity, and 45.9\% greater FHB index means than MR cultivars. Fungicide treatments did not manage FHB symptoms when contrasted to the nonfungicide control for MS cultivars; however, fungicide resulted in $9.5 \%$ fewer FHB incidence symptoms and $13.2 \%$ lower FHB index for MR cultivars (Table 4). Knudson had $22.5 \%$ fewer FHB incidence symptoms compared with the two more resistant cultivars within the nonfungicide control and showed $30.7 \%$ fewer FHB incidence symptoms from fungicide application (Table 4). Disease symptoms on Alsen and Walworth were not managed by fungicide application compared with the nonfungicide control. Symptoms of FHB on Knudson were routinely managed by fungicide application. The cultivar showed $16.4 \%$ less FHB incidence and $4.7 \%$ less FHB severity symptoms which resulted in $14.7 \%$ lower FHB index means from fungicide application (Table 4).

Without exception, FHB incidence, FHB severity, and FHB index means were greater in ENV2 compared with ENV1 (Table 5). In ENV1, MR cultivars showed 28.8, 26.5, and 60\% less FHB incidence, severity, and index, respectively, than MS cultivars. A similar outcome was noted in ENV2, where MR cultivars had 21.7, 27.4, and $42.9 \%$ less FHB incidence, severity, and index, respectively, than MS cultivars (Table 5).

Table 2. Summary of PROC MIXED analyses for variance of five hard red spring wheat cultivars and four fungicide treatments tested in eight locations in northwest Minnesota during 2004 and 2005

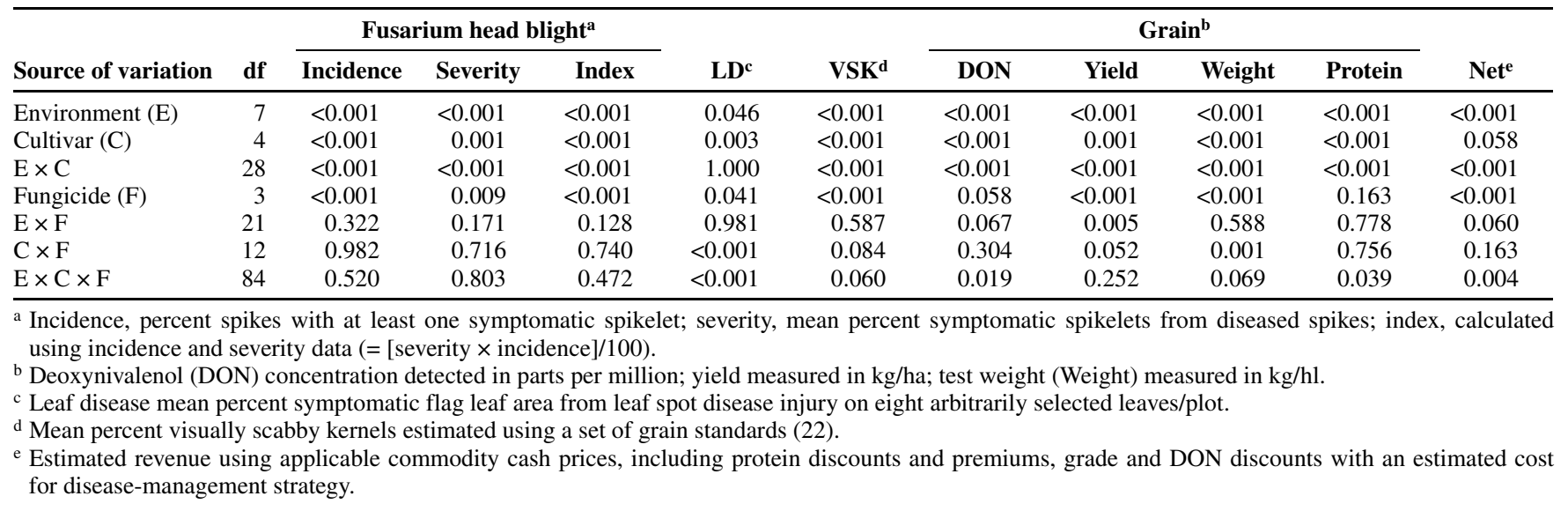


Cultivar responses from fungicide treatments were not significant for FHB incidence, FHB severity, or FHB index between ENV1 and ENV2 (Table 6). Regardless of environment, fungicide application managed symptoms of FHB incidence more consistently than FHB severity. In ENV1, fungicide application prevented a $10 \%$ increase in FHB incidence when compared with the nonfungicide control. In ENV2, when FHB incidence symptoms were more severe, the difference between the nonfungicide control and fungicide application treatments was $6.1 \%$. FHB incidence symptoms were $14.4 \%$ greater in ENV1 from the FGS 2 treatment compared with the FGS 2 + FGS 10.51 treatment (Table 6).

Grain yield and kernel quality. Up to four sources of variation were significant for VSK, DON, or protein (Table 2). Estimate means from ENV1 were $73.7 \%$ less for VSK, $75.0 \%$ less for DON, and $6 \%$ less for protein but $31.1 \%$ greater for yield and
4.7\% greater for test weight when compared with ENV2 (Table 3). BLUEs were not significant for yield between cultivars. As a group, MR cultivars produced grain with fewer VSK, less DON, and greater test weights than MS cultivars. Grain from Alsen and Walworth had 57\% fewer VSK, $41.2 \%$ less DON, $7.8 \%$ more protein, and $1.2 \%$ greater test weights than grain from Knudson (Table 3). When compared with Walworth, Alsen grain had $3.3 \%$ greater test weight and $3.7 \%$ more protein. Grain from Reeder had $2.1 \%$ greater protein and contained $37.5 \%$ more DON than grain from Oxen. Reeder grain accumulated DON at $180 \%$ of the grand mean. Its toxin levels exceeded $5 \mathrm{ppm}$ in ENV2 from three treatments, with concentrations of 5.6, 5.6, and $7.1 \mathrm{ppm}$ at the Oklee, Fergus Falls, and Perley locations, respectively.

Fungicide application resulted in $17.4 \%$ fewer VSK, $4.5 \%$ greater yields, and $0.5 \%$ higher test weights when compared with the nonfungicide control (Table 3). Yield and test weight were 4.5 and $0.7 \%$ greater, respectively, from the FGS 2 + FGS 10.51 treatment compared with the FGS 2 treatment (Table 3).

Overall, $7.8 \%$ larger yields were produced by MR cultivars compared with MS cultivars within the nonfungicide control whereas differences were not significant with fungicide application (Table 4). Yields from MR cultivars did not vary significantly between the nonfungicide control and fungicide application treatments, whereas MS cultivar yield responses were significantly improved by fungicide application. No differences were determined when Alsen and Walworth were contrasted against Knudson within or between fungicide treatments or cultivars (Table 4). MR and MS cultivars produced 29.8 and $35.4 \%$ less yield, respectively, in ENV2 compared with ENV1 (Table 5). MR cultivars produced $11.7 \%$ greater yields in ENV2 when disease pressure was higher compared with MS cultivars. Significant yield differences

Table 3. Summary of mean estimates, best linear unbiased estimates (BLUEs), and best linear unbiased predictions (BLUPs) from PROC MIXED analyses of five hard red spring wheat cultivars grown in eight locations in northwest Minnesota during 2004 and 2005 after exposure to four fungicide treatments $^{\mathrm{a}}$

\begin{tabular}{|c|c|c|c|c|c|c|c|c|c|c|c|}
\hline \multirow[b]{2}{*}{ No. } & \multirow[b]{2}{*}{ Estimate } & \multicolumn{3}{|c|}{ Fusarium head blight $(\mathrm{FHB})^{\mathrm{b}}$} & \multirow[b]{2}{*}{$\begin{array}{l}\text { LD } \\
(\%)^{\mathrm{c}}\end{array}$} & \multirow[b]{2}{*}{$\begin{array}{l}\text { VSK } \\
(\%)^{d}\end{array}$} & \multicolumn{4}{|c|}{ Grain } & \multirow[b]{2}{*}{$\begin{array}{l}\text { Net } \\
(\$ / \mathbf{h a})^{\mathrm{f}}\end{array}$} \\
\hline & & $\begin{array}{c}\text { Incidence } \\
(\%)\end{array}$ & $\begin{array}{c}\text { Severity } \\
(\%)\end{array}$ & $\begin{array}{c}\text { Index } \\
(\%)\end{array}$ & & & $\begin{array}{c}\text { DON } \\
(\mathbf{p p m})^{\mathrm{e}}\end{array}$ & $\begin{array}{l}\text { Yield } \\
(\mathrm{kg} / \mathrm{ha})\end{array}$ & $\begin{array}{c}\text { Test weight } \\
\text { kg/hl }\end{array}$ & $\begin{array}{c}\text { Protein } \\
(\%)\end{array}$ & \\
\hline & Environment ${ }^{\mathrm{g}}$ & & & & & & & & & & \\
\hline 1 & ENV1 & 28.7 & 9.3 & 2.7 & 6.5 & 1.0 & 0.8 & $6,361.3$ & 77.9 & 14.1 & 827.80 \\
\hline \multirow[t]{2}{*}{2} & $\begin{array}{l}\text { ENV2 } \\
\text { BLUP }\end{array}$ & 45.5 & 13.3 & 7.0 & 5.8 & 3.8 & 3.2 & $4,385.4$ & 74.2 & 15.0 & 555.60 \\
\hline & $\begin{array}{c}1 \text { vs. } 2 \\
\text { Cultivar }^{\mathrm{h}}\end{array}$ & $16.8 * *$ & $4.0 * *$ & $4.3^{* *}$ & $0.7^{\mathrm{NS}}$ & $2.8^{* *}$ & $2.4 * *$ & $1,975.9 * *$ & $3.7 * *$ & $0.9 * *$ & $272.20 * *$ \\
\hline 1 & Alsen & 33.7 & 8.4 & 2.5 & 5.4 & 0.3 & 0.8 & $5,677.6$ & 79.0 & 15.0 & 727.94 \\
\hline 2 & Knudson & 25.6 & 10.2 & 3.0 & 5.9 & 2.1 & 1.7 & $5,956.1$ & 76.6 & 13.6 & 675.78 \\
\hline 3 & Oxen & 45.4 & 12.6 & 6.4 & 6.4 & 3.0 & 2.0 & $5,585.0$ & 74.8 & 14.3 & 737.08 \\
\hline 4 & Reeder & 40.2 & 13.2 & 5.9 & 6.4 & 3.3 & 3.2 & $5,463.4$ & 75.3 & 14.6 & 713.06 \\
\hline \multirow[t]{6}{*}{5} & $\begin{array}{l}\text { Walworth } \\
\text { BLUE }\end{array}$ & 38.0 & 11.0 & 4.7 & 6.9 & 1.4 & 1.2 & $5,860.7$ & 76.1 & 14.5 & 713.99 \\
\hline & $1,2,5$ vs. 3,4 & $10.4 * *$ & $3.0^{* *}$ & $2.7 * *$ & $0.3^{\mathrm{NS}}$ & $1.9^{* *}$ & $1.4^{* *}$ & $307.3^{\mathrm{NS}}$ & $2.2 * *$ & $0.1^{\mathrm{NS}}$ & $19.16^{\mathrm{NS}}$ \\
\hline & 1,5 vs. 2 & $10.3 * *$ & $0.5^{\mathrm{NS}}$ & $0.6^{\mathrm{NS}}$ & $0.2^{\mathrm{NS}}$ & $1.2 * *$ & $0.7 *$ & $186.9^{\mathrm{NS}}$ & $0.9^{*}$ & $1.2^{* *}$ & $45.18^{\mathrm{NS}}$ \\
\hline & 1 vs. 5 & $4.3^{\mathrm{NS}}$ & $2.6^{\mathrm{NS}}$ & $2.2^{\mathrm{NS}}$ & $1.6^{\mathrm{NS}}$ & $1.1^{\mathrm{NS}}$ & $0.4^{\mathrm{NS}}$ & $183.1^{\mathrm{NS}}$ & $3.0 * *$ & $0.4^{* *}$ & $13.94^{\mathrm{NS}}$ \\
\hline & 3 vs. 4 & $5.2 *$ & $0.5^{\mathrm{NS}}$ & $0.5^{\mathrm{NS}}$ & $0.1^{\mathrm{NS}}$ & $0.3^{\mathrm{NS}}$ & $1.2^{* *}$ & $121.6^{\mathrm{NS}}$ & $0.4^{\mathrm{NS}}$ & $0.4^{* *}$ & $24.02^{\mathrm{NS}}$ \\
\hline & Treatment ${ }^{\mathrm{i}}$ & & & & & & & & & & \\
\hline 1 & Nontreated & 37.3 & 11.3 & 4.7 & 6.1 & 2.3 & 1.8 & $5,428.7$ & 76.2 & 14.4 & 704.23 \\
\hline 2 & FGS 2 & 37.4 & 11.1 & 4.7 & 7.5 & 2.1 & 1.8 & $5,544.7$ & 76.3 & 14.5 & 718.15 \\
\hline 3 & FGS 10.51 & 32.3 & 10.4 & 4.0 & 5.5 & 1.8 & 1.6 & $5,704.6$ & 76.6 & 14.4 & 738.34 \\
\hline \multirow[t]{3}{*}{4} & $\begin{array}{l}\text { FGS } 2+\text { FGS } 10.51 \\
\text { BLUE }\end{array}$ & 33.0 & 10.5 & 4.0 & 5.9 & 1.8 & 1.6 & $5,803.4$ & 76.8 & 14.4 & 742.20 \\
\hline & 1 vs. $2,3,4$ & $3.0 * *$ & $0.6^{\mathrm{NS}}$ & $0.5^{*}$ & $0.2^{\mathrm{NS}}$ & $0.4^{*}$ & $0.1^{\mathrm{NS}}$ & $255.6^{* *}$ & $0.4 * *$ & $0.0^{\mathrm{NS}}$ & $28.67 * *$ \\
\hline & 2 vs. 4 & $4.4^{* *}$ & $0.6^{\mathrm{NS}}$ & $0.6^{* *}$ & $1.6^{* *}$ & $0.3^{\mathrm{NS}}$ & $0.2^{\mathrm{NS}}$ & $258.6^{* *}$ & $0.4 * *$ & $0.0^{\mathrm{NS}}$ & $24.05^{* *}$ \\
\hline
\end{tabular}

${ }^{a} \mathrm{NS}=$ contrast differences not significant at $P \leq 0.05$; * and $* *$ significant at the 0.05 and 0.001 levels, respectively.

${ }^{b}$ Incidence, percent spikes from 50 rated/plot with at least one symptomatic spikelet; severity, mean percent symptomatic spikelets from diseased spikes; index, calculated using incidence and severity data (= [severity $\times$ incidence $] / 100)$.

${ }^{\mathrm{c}}$ Leaf disease mean percent symptomatic flag leaf area from leaf spot disease injury on eight arbitrarily selected leaves/plot. Ratings include injury from tan spot caused by Pyrenophora tritici-repentis (Died.) Drechsler; Stagonospora leaf blotch, caused by Stagonospora nodorum (Berk.) Castell. \& Germano; and Septoria tritici blotch, caused by Septoria tritici Desm., leaf rust caused by Puccinia triticina (Roberge ex Desmaz. f. sp. tritici), and stripe rust caused by Puccinia striiformis Westend. f. sp. tritici.

${ }^{\mathrm{d}}$ Mean percent visually scabby kernels estimated using a set of grain standards (22).

e Deoxynivalenol.

${ }^{\mathrm{f}}$ Estimated revenue using applicable commodity cash prices, including protein discounts and premiums, grade, and DON discounts with an estimated cost for disease management strategy.

g Test environments were characterized as having either slight FHB (ENV1; five test locations in 2004) or moderate disease (ENV2: three test locations in 2005) development.

${ }^{\mathrm{h}}$ Cultivar resistance ratings on a scale from 1 to 9 , where 1 is most resistant and 9 is most susceptible to FHB; Alsen $=4$, Walworth $=5$, Knudson $=6$, Reeder $=7$, and Oxen $=8(2)$.

${ }^{\text {i }}$ Fungicide treatment: 1, nonfungicide control; 2, Feekes growth stage (FGS) 2 application at the four- to five-leaf crop growth stage using propiconazole (Tilt $3.6 \mathrm{EC}$ ) at $0.06 \mathrm{~kg}$ active ingredient (a.i.)/ha; 3, FGS 10.51 application at the early-anthesis crop growth stage using tebuconazole (Folicur $3.6 \mathrm{~F}$ ) at $0.13 \mathrm{~kg}$ a.i./ha; and 4, FGS 2 application of propiconazole (Tilt $3.6 \mathrm{EC}$ ) at $0.06 \mathrm{~kg}$ a.i./ha followed by a FGS 10.51 application of tebuconazole (Folicur 3.6 F) at $0.13 \mathrm{~kg}$ a.i./ha (FGS 2+FGS 10.51). All fungicide application treatments included $0.125 \%$ Induce, a nonionic surfactant. 
were identified between environments within cultivar but not between cultivars within environment for MR (Alsen versus Walworth) and MS (Oxen versus Reeder) cultivars (Table 5). Numerical yield losses between environments trended slightly higher for MS cultivars (Oxen, 35.2\% and Reeder, $35.6 \%$ ) compared with MR cultivars (Alsen, 30.4\% and Walworth, 29.2\%). Fungicide application increased yields $3.9 \%$ in ENV1 and $6.0 \%$ in ENV2 compared with the nonfungicide control (Table 6). BLUPs showed that the FGS 2 treatment was 4.0 and $5.5 \%$ less effective at preserving yield than the FGS $2+$ FGS 10.51 treatment in ENV1 and ENV2, respectively.
Fungicide application did not increase grain test weights of MR cultivars; however, test weights of MS cultivars increased by $1.1 \%$ (Table 4). Test weights of MR cultivars were significantly greater than those of MS cultivars when contrasted within the fungicide application or nontreated control treatments. Grain from Alsen and Walworth resulted in $1.4 \%$ greater test weights than from Knudson when plants were not treated with fungicide but differences were not significant when fungicide was applied. MR and MS cultivars produced grain with 4.3 and $5.5 \%$ greater test weights, respectively, in ENV1 compared with ENV2 (Table 5). Compared with MS cultivars, grain from MR cultivars had 2.9 and $4.1 \%$ greater test weights in ENV1 and ENV2, respectively. Differences between MR (Alsen versus Walworth) and MS (Oxen versus Reeder) cultivars were significant for test weight between environments within cultivar as well as between cultivars within environment, with one exception. Differences were not significant in ENV1 between Oxen and Reeder. Between environment, losses in test weights trended slightly greater for MS cultivars (Oxen, 6.0\% and Reeder, 5.2\%) than MR cultivars (Alsen, $4.2 \%$ and Walworth, 4.3\%; Table 5). Fungicide treatment increased test weights by 0.5 and $0.5 \%$ in ENV1 and ENV2 compared with the nonfungicide control (Table

Table 4. Summary of mean estimates and best linear unbiased estimates (BLUEs) for cultivar-fungicide interactions from analyses of five hard red spring wheat cultivar responses to four fungicide treatments at five test locations in northwest Minnesota during 2004 and 2005

\begin{tabular}{|c|c|c|c|c|c|c|}
\hline \multirow[b]{2}{*}{ Parameter $^{c}$} & \multicolumn{3}{|c|}{ MR versus $\mathbf{M S}^{\mathbf{b}}$} & \multirow[b]{2}{*}{ Alsen, Walworth } & \multirow[b]{2}{*}{ Knudson } & \multirow[b]{2}{*}{ Difference } \\
\hline & Alsen, Knudson, Walworth & Oxen, Reeder & Difference & & & \\
\hline \multicolumn{7}{|c|}{ FHB incidence } \\
\hline Nontreated & 34.9 & 44.7 & $9.8^{* *}$ & 37.7 & 29.2 & $8.6^{*}$ \\
\hline Treated & 31.6 & 42.2 & $10.6^{* *}$ & 35.2 & 24.4 & $10.8 * *$ \\
\hline Difference & $3.2 *$ & $2.5^{\mathrm{NS}}$ & $\ldots$ & $2.5^{\mathrm{NS}}$ & $4.9 * *$ & $\ldots$ \\
\hline \multicolumn{7}{|l|}{ FHB severity } \\
\hline Nontreated & 10.3 & 13.2 & $2.9 * *$ & 10.2 & 10.6 & $0.5^{\mathrm{NS}}$ \\
\hline Treated & 9.7 & 12.8 & $3.1 * *$ & 9.5 & 10.1 & $0.6^{\mathrm{NS}}$ \\
\hline Difference & $0.6^{\mathrm{NS}}$ & $0.4^{\mathrm{NS}}$ & $\ldots$ & $0.7^{\mathrm{NS}}$ & $0.9^{*}$ & $\ldots$ \\
\hline \multicolumn{7}{|l|}{ FHB index } \\
\hline Nontreated & 3.8 & 6.5 & $2.6^{* *}$ & 4.0 & 3.4 & $0.7^{\mathrm{NS}}$ \\
\hline Treated & 3.3 & 6.1 & $2.8^{* *}$ & 3.5 & 2.9 & $0.6^{\mathrm{NS}}$ \\
\hline Difference & $0.5^{*}$ & $0.4^{\mathrm{NS}}$ & $\ldots$ & $0.5^{\mathrm{NS}}$ & $0.5^{*}$ & $\ldots$ \\
\hline \multicolumn{7}{|l|}{ Leaf disease } \\
\hline Nontreated & 6.6 & 5.5 & $1.1^{\mathrm{NS}}$ & 7.2 & 5.4 & $1.8^{*}$ \\
\hline Treated & 5.9 & 6.7 & $0.8^{\mathrm{NS}}$ & 5.8 & 6.1 & $0.3^{\mathrm{NS}}$ \\
\hline Difference & $0.6^{\mathrm{NS}}$ & $1.3 *$ & $\ldots$ & $1.3^{\mathrm{NS}}$ & $2.6^{* *}$ & $\ldots$ \\
\hline \multicolumn{7}{|l|}{ Yield } \\
\hline Nontreated & $5,711.6$ & $5,264.2$ & $447.4^{*}$ & $5,639.9$ & $5,854.9$ & $215.0^{\mathrm{NS}}$ \\
\hline Treated & $5,871.4$ & $5,610.8$ & $260.6^{\mathrm{NS}}$ & $5,812.2$ & $5,989.8$ & $177.5^{\mathrm{NS}}$ \\
\hline Difference & $159.8^{\mathrm{NS}}$ & $346.6 * *$ & $\ldots$ & $172.3^{\mathrm{NS}}$ & $167.8^{\mathrm{NS}}$ & $\ldots$ \\
\hline \multicolumn{7}{|l|}{ Test weight } \\
\hline Nontreated & 77.1 & 74.4 & $2.7 * *$ & 77.5 & 76.4 & $1.1^{*}$ \\
\hline Treated & 77.3 & 75.2 & $2.1 * *$ & 77.6 & 76.7 & $0.8^{\mathrm{NS}}$ \\
\hline Difference & $0.2^{\mathrm{NS}}$ & $0.8^{* *}$ & $\ldots$ & $0.1^{\mathrm{NS}}$ & $0.4^{*}$ & $\ldots$ \\
\hline \multicolumn{7}{|l|}{ Protein } \\
\hline Nontreated & 14.4 & 14.4 & $0.0^{\mathrm{NS}}$ & 14.8 & 13.6 & $1.2^{* *}$ \\
\hline Treated & 14.4 & 14.5 & $0.1^{\mathrm{NS}}$ & 14.8 & 13.6 & $1.2 * *$ \\
\hline Difference & $0.0^{\mathrm{NS}}$ & $0.1^{\mathrm{NS}}$ & $\ldots$ & $0.0^{\mathrm{NS}}$ & $0.1^{\mathrm{NS}}$ & $\ldots$ \\
\hline \multicolumn{7}{|l|}{ DON } \\
\hline Nontreated & 1.3 & 2.7 & $1.4 * *$ & 1.0 & 1.8 & $0.8^{*}$ \\
\hline Treated & 1.2 & 2.6 & $1.4^{* *}$ & 0.9 & 1.7 & $0.7 *$ \\
\hline Difference & $0.1^{\mathrm{NS}}$ & $0.1^{\mathrm{NS}}$ & $\ldots$ & $0.1^{\mathrm{NS}}$ & $0.1^{\mathrm{NS}}$ & $\ldots$ \\
\hline \multicolumn{7}{|l|}{ Net revenue } \\
\hline Nontreated & 687.93 & 703.63 & $15.70^{\mathrm{NS}}$ & 695.93 & 671.95 & $23.98^{\mathrm{NS}}$ \\
\hline Treated & 711.90 & 732.21 & $20.32^{\mathrm{NS}}$ & 729.31 & 677.06 & $52.25^{\mathrm{NS}}$ \\
\hline Difference & $24.00 *$ & $28.58 * *$ & $\ldots$ & $33.38 * *$ & $26.27 *$ & $\ldots$ \\
\hline
\end{tabular}

${ }^{a} \mathrm{NS}=$ contrast differences not significant at $P \leq 0.05 ; *$ and $* *$ significant at the 0.05 and 0.001 levels, respectively. Difference was calculated from estimate figures. Rounding may have caused slight discrepancies.

${ }^{\mathrm{b}}$ Cultivar ratings on a scale from 1 to 9 , where 1 is most resistant and 9 is most susceptible to Fusarium head blight $(\mathrm{FHB})$; Alsen $=4$, Walworth $=5$, Knudson $=6$, Reeder $=7$, and Oxen $=8$ (2). Alsen, Knudson, and Walworth were grouped to test responses of cultivars with moderate levels of resistance to FHB (MR) while Reeder and Oxen were grouped to test responses of cultivars with moderately susceptible levels of resistance to FHB (MS).

${ }^{\mathrm{c}}$ FHB incidence, percent spikes of 50/plot with at least one symptomatic spikelet; FHB severity, mean percent symptomatic spikelets from diseased spikes; FHB index, calculated using incidence and severity data (= [severity $\times$ incidence]/100); leaf disease, mean percent symptomatic flag leaf area from leaf spot disease injury on eight arbitrarily selected leaves/plot. Ratings include injury from tan spot caused by Pyrenophora tritici-repentis, Stagonospora leaf blotch caused by Stagonospora nodorum, Septoria tritici blotch caused by Septoria tritici, leaf rust caused by Puccinia triticina, and stripe rust caused by Puccinia striiformis; yield in kg/ha; test weight in $\mathrm{kg} / \mathrm{hl}$; protein in percent; DON, deoxynivalenol in parts per million; net revenue, estimated using applicable commodity cash prices and an estimate cost for disease management strategy, expressed as $\$ /$ ha. Nontreated $=$ no fungicide applied; Treated $=$ response mean of three fungicide application treatments: 1, Feekes growth stage (FGS) 2 application at the four- to five-leaf crop growth stage using propiconazole (Tilt $3.6 \mathrm{EC}$ ) at $0.06 \mathrm{~kg}$ active ingredient (a.i.)/ha; 2, FGS 10.51 application at the early-anthesis crop growth stage using tebuconazole (Folicur $3.6 \mathrm{~F}$ ) at $0.13 \mathrm{~kg}$ a.i./ha; and 3, FGS 2 application of propiconazole (Tilt $3.6 \mathrm{EC}$ ) at $0.06 \mathrm{~kg}$ a.i./ha followed by a FGS 10.51 application of tebuconazole (Folicur 3.6 F) at $0.13 \mathrm{~kg}$ a.i./ha. All fungicide application treatments included $0.125 \%$ Induce, a nonionic surfactant. 
6). The FGS 2 treatment was 0.6 and $0.7 \%$ less effective at preserving test weights than the FGS $2+$ FGS 10.51 treatment in ENV1 and ENV2, respectively.

Fungicide application did not benefit grain protein content of MR or MS cultivars (Table 4). Grain protein from Alsen and Walworth was $8.1 \%$ greater than protein from Knudson whether or not plants were treated with fungicide. Grain protein is inversely correlated with yield and influenced by cultivar characteristics. Protein data shown in Table 5 illustrate environment and quality characteristics of cultivars that are largely disengaged from diseasemanagement strategy. Results illustrated in Table 6 indicate BLUP effects from environment $\times$ fungicide treatment interactions that reflect cultivar characteristics rather than fungicide application influences.

Fungicide application did not prevent DON accumulation in grain of MR or MS cultivars (Table 4). Grain DON content from MR cultivars was 51.9 and $53.8 \%$ less than MS cultivars when contrasted within fungicide-applied and nontreated treatments, respectively. Grain from Alsen and Walworth contained 44.4 and $47.1 \%$ less DON than grain from Knudson when compared within fungicide-applied and nontreated treatments, respectively (Table 4). Grain from MR and MS cultivars had 88.5 and $61.4 \%$ greater DON content, respectively, in ENV2 compared with ENV1 (Table 5). MR cultivars had 82.4 and $40.9 \%$ less DON in ENV1 and ENV2, respectively, compared with MS cultivars. MR (Alsen versus Walworth) cultivars had significant differences in DON accumulation between environments within cultivar but not between cultivars within environment. MS (Oxen versus Reeder) cultivars had differences in DON accumulation between environments within cultivar as well as between cultivars within environment (Table 5). Fungicide application pre- vented $11.1 \%$ of DON from ENV1 compared with the nonfungicide control (Table $6)$. BLUPs showed that the FGS 2 treatment was $22.2 \%$ less effective at preventing DON than the FGS $2+$ FGS 10.51 treatment in ENV1 whereas differences between treatments were not significant in ENV2.

Revenue returned. Net returns from ENV1 were $32.9 \%$ greater than from ENV2 (Table 3). BLUPs conducted on cultivar were not significant. Fungicide application resulted in $3.9 \%$ greater net returns when compared with the nonfungicide control (Table 3). When the FGS 2 treatment was compared with the FGS $2+$ FGS 10.51 treatment, returns were increased by $3.2 \%$ from the latter.

Fungicide application increased net revenue from MR as well as MS cultivars (Table 4). Revenue of MR and MS cultivars was increased by 3.4 and $3.9 \%$, respectively. Numerically, MS cultivars

Table 5. Summary of mean estimates and best linear unbiased predictions (BLUPs) for environment $\times$ cultivar interactions from analyses of five hard red spring wheat cultivar responses across four fungicide treatments at eight test locations in northwest Minnesota during 2004 and $2005^{\mathrm{a}}$

\begin{tabular}{|c|c|c|c|c|c|c|c|c|c|}
\hline \multirow[b]{2}{*}{ Parameter $^{\mathrm{b}}$} & \multicolumn{3}{|c|}{ MR versus MS } & \multicolumn{3}{|c|}{$\mathrm{MR}_{1}$ versus $\mathrm{MR}_{2}$} & \multicolumn{3}{|c|}{$\mathbf{M S}_{1}$ versus $\mathbf{M S}_{2}$} \\
\hline & A-K-W & O-R & Diff. & Alsen & Walworth & Diff. & Oxen & Reeder & Diff. \\
\hline \multicolumn{10}{|c|}{ FHB incidence } \\
\hline ENV1 & 26.0 & 36.5 & $10.5 * *$ & 27.0 & 31.7 & $4.7^{\mathrm{NS}}$ & 37.8 & 35.2 & $2.6^{\mathrm{NS}}$ \\
\hline ENV2 & 42.5 & 54.3 & $11.9^{* *}$ & 44.2 & 46.4 & $2.2^{\mathrm{NS}}$ & 55.8 & 52.9 & $3.0^{\mathrm{NS}}$ \\
\hline Difference & $16.3^{* *}$ & $17.8 * *$ & $\ldots$ & $17.2^{* * *}$ & $14.7 * *$ & $\ldots$ & $18.0 * *$ & $17.7 * *$ & $\ldots$ \\
\hline \multicolumn{10}{|l|}{ FHB severity } \\
\hline ENV1 & 8.3 & 11.3 & $3.0^{*}$ & 7.1 & 9.5 & $2.3^{\mathrm{NS}}$ & 10.3 & 12.3 & $2.0^{\mathrm{NS}}$ \\
\hline ENV2 & 11.9 & 16.4 & $4.5^{* *}$ & 10.9 & 12.4 & $1.5^{*}$ & 15.7 & 17.1 & $1.4^{*}$ \\
\hline Difference & $3.5^{* *}$ & $5.2 * *$ & $\ldots$ & $3.8^{*}$ & $3.0 *$ & $\ldots$ & $5.5^{* *}$ & $4.9 * *$ & $\ldots$ \\
\hline \multicolumn{10}{|l|}{ FHB index } \\
\hline ENV1 & 1.8 & 4.5 & $2.7 * *$ & 1.3 & 3.1 & $1.9^{\mathrm{NS}}$ & 4.0 & 4.9 & $0.9^{\mathrm{NS}}$ \\
\hline ENV2 & 5.6 & 9.8 & $4.2^{* *}$ & 5.2 & 6.4 & $1.2^{*}$ & 9.8 & 9.9 & $0.2^{\mathrm{NS}}$ \\
\hline Difference & $3.8^{* *}$ & $5.4 * *$ & $\ldots$ & $4.0^{* *}$ & $3.3^{* *}$ & $\ldots$ & $5.7 * *$ & $5.0 * *$ & $\ldots$ \\
\hline \multicolumn{10}{|l|}{ Yield } \\
\hline ENV1 & $6,592.6$ & $6,326.9$ & $265.7^{\mathrm{NS}}$ & $6,387.1$ & $6,601.7$ & $214.6^{\mathrm{NS}}$ & $6,477.5$ & $6,176.3$ & $301.3^{\mathrm{NS}}$ \\
\hline ENV2 & $4,629.6$ & $4,086.3$ & $543.3 * *$ & $4,442.7$ & $4,672.5$ & $229.8^{\mathrm{NS}}$ & $4,196.9$ & $3,975.8$ & $221.1^{\mathrm{NS}}$ \\
\hline \multirow{2}{*}{\multicolumn{10}{|c|}{ Test weight }} \\
\hline & & & & & & & & & \\
\hline ENV1 & 78.7 & 76.4 & $2.2 * *$ & 80.1 & 77.5 & $2.7 * *$ & 76.5 & 76.4 & $0.1^{\mathrm{NS}}$ \\
\hline ENV2 & 75.3 & 72.2 & $3.1 * *$ & 76.7 & 74.2 & $2.5 * *$ & 71.9 & 72.4 & $0.5^{*}$ \\
\hline Difference & $3.4 * *$ & $4.3 * *$ & $\ldots$ & $3.4 * *$ & $3.2 * *$ & $\ldots$ & $4.6 * *$ & $3.9 * *$ & $\ldots$ \\
\hline \multicolumn{10}{|l|}{ Protein } \\
\hline ENV1 & 14.0 & 14.1 & $0.1^{\mathrm{NS}}$ & 14.7 & 14.2 & $0.5^{*}$ & 13.9 & 14.2 & $0.3^{*}$ \\
\hline ENV2 & 15.0 & 15.1 & $0.1^{*}$ & 15.6 & 15.2 & $0.4 * *$ & 14.9 & 15.2 & $0.3^{* *}$ \\
\hline Difference & $0.9 * *$ & $1.0 * *$ & $\ldots$ & $0.9 * *$ & $1.0 * *$ & $\ldots$ & $1.0 * *$ & $1.0 * *$ & $\ldots$ \\
\hline \multicolumn{10}{|l|}{ DON } \\
\hline ENV1 & 0.3 & 1.7 & $1.4^{* *}$ & 0.2 & 0.3 & $0.1^{\mathrm{NS}}$ & 0.8 & 2.6 & $1.8^{*}$ \\
\hline ENV2 & 2.6 & 4.4 & $1.8 * *$ & 2.3 & 2.1 & $0.1^{\mathrm{NS}}$ & 3.5 & 5.3 & $1.8^{* *}$ \\
\hline Difference & $2.3 * *$ & $2.7 * *$ & $\ldots$ & $2.5^{* *}$ & $1.9 * *$ & $\ldots$ & $2.8^{* *}$ & $2.7 * *$ & $\ldots$ \\
\hline \multicolumn{10}{|l|}{ Net revenue } \\
\hline ENV1 & 790.20 & 858.51 & $68.31 *$ & 800.45 & 807.14 & $6.69^{\mathrm{NS}}$ & 856.36 & 860.66 & $4.29^{\mathrm{NS}}$ \\
\hline ENV2 & 524.06 & 565.59 & $41.53^{\mathrm{NS}}$ & 538.65 & 500.37 & $38.28^{\mathrm{NS}}$ & 607.65 & 523.53 & $84.13 *$ \\
\hline Difference & $265.13^{* *}$ & $292.92 * *$ & $\ldots$ & $261.80 * *$ & $306.77 * *$ & $\ldots$ & $248.71 * *$ & $337.13 * *$ & $\ldots$ \\
\hline
\end{tabular}

a Ratings of cultivars on a scale from 1 to 9 , where 1 is most resistant and 9 is most susceptible to Fusarium head blight $(\mathrm{FHB})$; Alsen $=4$, Walworth $=5$, Knudson $=6$, Reeder $=7$, and Oxen $=8$ (2). Alsen, Knudson, and Walworth $(\mathrm{A}-\mathrm{K}-\mathrm{W})$ were grouped together to test responses of cultivars with moderate levels of resistance to FHB (MR) while Reeder and Oxen (R-O) were grouped to test responses of cultivars with moderately susceptible levels of resistance of FHB (MS). Diff. = differences calculated from estimate figures. Rounding may have caused slight discrepancies. NS $=$ contrast differences not significant at $P \leq 0.05 ; *$ and ** significant at the 0.05 and 0.001 levels, respectively.

${ }^{\mathrm{b}}$ FHB incidence, percent spikes 50/plot with at least one symptomatic spikelet; FHB severity, mean percent symptomatic spikelets from diseased spikes; FHB index, calculated using incidence and severity data (= [severity $\times$ incidence $] / 100)$; yield in $\mathrm{kg} / \mathrm{ha}$; test weight in $\mathrm{kg} / \mathrm{hl}$; protein in percent; DON, deoxynivalenol in parts per million; net revenue, estimated using applicable commodity cash prices and an estimated cost for disease management strategy, expressed as \$/ha. Cultivar mean responses from experiments including four fungicide treatments: 1, nontreated; 2, Feekes growth stage (FGS) 2 application at the four- to five-leaf crop growth stage using propiconazole (Tilt $3.6 \mathrm{EC}$ ) at $0.06 \mathrm{~kg}$ active ingredient (a.i.)/ha; 3 , FGS 10.51 application at the early-anthesis crop growth stage using tebuconazole (Folicur 3.6 F) at $0.13 \mathrm{~kg}$ a.i./ha; and 4, FGS 2 application of propiconazole (Tilt 3.6 EC) at $0.06 \mathrm{~kg}$ a.i./ha followed by a FGS 10.51 application of tebuconazole (Folicur $3.6 \mathrm{~F}$ ) at $0.13 \mathrm{~kg}$ a.i./ha. All fungicide application treatments included $0.125 \%$ Induce, a nonionic surfactant, at five sites during 2004 (ENV1) where FHB development was low and three during 2005 (ENV2) where FHB development was moderate. 
trended toward larger economic returns than MR cultivars but differences were not significant. An application of fungicide on Alsen and Walworth resulted in a $4.6 \%$ increase in revenue, whereas a $0.8 \%$ increase occurred when Knudson was treated with fungicide (Table 4). MR and MS cultivars had 33.7 and $34.1 \%$ greater revenues, respectively, from ENV1 compared with ENV2 (Table 5). In ENV1, MR cultivars had an $8.0 \%$ net revenue disadvantage compared with MS cultivars but the two groups of cultivars were not significantly different in ENV2. MR (Alsen versus Walworth) and MS (Oxen versus Reeder) cultivars showed significant revenue differences between environments within cultivar but not between cultivars within environment, with one exception (Table 5). Oxen returned $13.8 \%$ more net revenue compared with Reeder in ENV2. Fungicide application increased net revenues by 3.7 and $4.5 \%$ in ENV1 and ENV2, respectively, compared with the nonfungicide control (Table 6). BLUPs showed that the
FGS 2 treatment was 3.2 and $3.5 \%$ less economically effective in ENV1 and ENV2, respectively, than the FGS 2 + FGS 10.51 treatment.

\section{DISCUSSION}

This research was conducted to investigate agronomic and economic outcomes of implementing recommended disease management strategies on hard red spring wheat. Our results indicate that (i) net revenues are greater for MS compared with MR cultivars in environments that do not promote FHB, and similar in environments where moderate levels of FHB exist; and (ii) environments that promoted FHB caused reduced grain yields and kernel test weights while increasing VSKs, DON, and protein in all cultivars compared with lowdisease environments. MR cultivars yielded similarly to MS cultivars in environments with low levels of FHB but had better quality grain with larger test weights and lower DON levels. In an environment with moderate FHB, MR cultivars pro- duced larger yields and test weights with lower DON and protein levels than MS cultivars. Fungicide application increased yields and test weights of MR cultivars over those of MS cultivars in both disease environments but had no effect on protein and a limited effect on DON. MR cultivars had significantly lower DON levels than MS in low-disease environments but were similar in moderate FHB environments.

Although this study was conducted using small on-farm field research plots, disease management outcomes are expected to be similar when management strategies are used on a much larger scale for commercial grain producers.

Less than $7 \%$ of flag leaf tissues were damaged by foliar disease during each year of this study and no significant differences in disease severity were identified between environments or cultivars. A relatively constant level of foliar disease injury was present in each environment which may or may not have contributed to yield and quality losses herein attributed to FHB.

Table 6. Summary of mean estimates and best linear unbiased predictions (BLUPs) for environment $\times$ fungicide interactions from analyses of five hard red spring wheat cultivar response to four fungicide treatments at eight test locations in northwest Minnesota during 2004 and 2005

\begin{tabular}{|c|c|c|c|c|c|c|c|c|c|}
\hline \multirow[b]{2}{*}{ Parameter $^{\mathbf{b}}$} & \multicolumn{3}{|c|}{ Fungicide treatment } & \multicolumn{3}{|c|}{ Fungicide treatment } & \multicolumn{3}{|c|}{ Fungicide treatment } \\
\hline & 1 & $2,3,4$ & Diff. & 2 & 4 & Diff. & 3 & 2,4 & Diff. \\
\hline \multicolumn{10}{|c|}{ FHB incidence } \\
\hline ENV1 & 31.0 & 27.9 & $3.0 *$ & 31.2 & 26.7 & $4.5^{* *}$ & 26.0 & 28.9 & $2.9 *$ \\
\hline ENV2 & 47.7 & 44.8 & $3.0^{*}$ & 47.8 & 43.6 & $4.3^{*}$ & 42.9 & 45.7 & $2.8^{*}$ \\
\hline Difference & $16.8^{\mathrm{NS}}$ & $16.8^{\mathrm{NS}}$ & & $16.7^{\mathrm{NS}}$ & $16.9^{\mathrm{NS}}$ & & $16.9^{\mathrm{NS}}$ & $16.8^{\mathrm{NS}}$ & \\
\hline \multicolumn{10}{|l|}{ FHB severity } \\
\hline ENV1 & 9.7 & 9.2 & $0.6^{\mathrm{NS}}$ & 9.6 & 9.0 & $0.6^{\mathrm{NS}}$ & 8.9 & 9.3 & $0.4^{\mathrm{NS}}$ \\
\hline ENV2 & 13.9 & 13.2 & $0.7 *$ & 13.7 & 12.9 & $0.7^{\mathrm{NS}}$ & 12.9 & 13.3 & $0.4^{\mathrm{NS}}$ \\
\hline Difference & $4.2^{\mathrm{NS}}$ & $4.0^{\mathrm{NS}}$ & & $4.1^{\mathrm{NS}}$ & $3.9^{\mathrm{NS}}$ & & $4.0^{\mathrm{NS}}$ & $4.0^{\mathrm{NS}}$ & \\
\hline \multicolumn{10}{|l|}{ FHB index } \\
\hline ENV1 & 3.1 & 2.6 & $0.5^{*}$ & 3.1 & 2.4 & $0.6^{*}$ & 2.3 & 2.7 & $0.4^{*}$ \\
\hline ENV2 & 7.4 & 6.9 & $0.5^{*}$ & 7.3 & 6.7 & $0.6^{*}$ & 6.7 & 7.0 & $0.3^{\mathrm{NS}}$ \\
\hline Difference & $4.3^{\mathrm{NS}}$ & $4.3^{\mathrm{NS}}$ & & $4.2^{\mathrm{NS}}$ & $4.3^{\mathrm{NS}}$ & & $4.3^{\mathrm{NS}}$ & $4.3^{\mathrm{NS}}$ & \\
\hline \multicolumn{10}{|l|}{ Yield } \\
\hline ENV1 & $6,176.4$ & $6,424.7$ & $248.3 * *$ & $6,281.2$ & $6,545.5$ & $264.3 * *$ & $6,447.5$ & $6,413.4$ & $34.1^{\mathrm{NS}}$ \\
\hline ENV2 & $4,182.4$ & $4,450.1$ & $267.6^{* *}$ & $4,317.3$ & $4,566.5$ & $249.2 * *$ & $4,466.5$ & $4,441.9$ & $24.6^{\mathrm{NS}}$ \\
\hline Difference & $1,994.0^{\mathrm{NS}}$ & $1,974.7^{\mathrm{NS}}$ & & $1,964.0^{\mathrm{NS}}$ & $1,979.0^{\mathrm{NS}}$ & & $1,981.0^{\mathrm{NS}}$ & $1,971.5^{\mathrm{NS}}$ & \\
\hline \multicolumn{10}{|l|}{ Test weight } \\
\hline ENV1 & 77.6 & 78.0 & $0.4^{* *}$ & 77.7 & 78.2 & $0.4 * *$ & 78.0 & 77.9 & $0.1^{\mathrm{NS}}$ \\
\hline ENV2 & 73.9 & 74.3 & $0.4^{* *}$ & 74.0 & 74.5 & $0.4^{*}$ & 74.3 & 74.3 & $0.1^{\mathrm{NS}}$ \\
\hline Difference & $3.7^{\mathrm{NS}}$ & $3.7^{\mathrm{NS}}$ & & $3.7^{\mathrm{NS}}$ & $3.7^{\mathrm{NS}}$ & & $3.7^{\mathrm{NS}}$ & $3.7^{\mathrm{NS}}$ & \\
\hline \multicolumn{10}{|l|}{ Protein } \\
\hline ENV1 & 14.0 & 14.1 & $0.0^{\mathrm{NS}}$ & 14.1 & 14.1 & $0.0^{\mathrm{NS}}$ & 14.1 & 14.1 & $0.0^{\mathrm{NS}}$ \\
\hline ENV2 & 15.0 & 15.0 & $0.0^{\mathrm{NS}}$ & 15.0 & 15.0 & $0.0^{\mathrm{NS}}$ & 15.0 & 15.0 & $0.0^{\mathrm{NS}}$ \\
\hline Difference & $0.9^{\mathrm{NS}}$ & $0.9^{\mathrm{NS}}$ & & $0.9^{\mathrm{NS}}$ & $0.9^{\mathrm{NS}}$ & & $0.9^{\mathrm{NS}}$ & $0.9^{\mathrm{NS}}$ & \\
\hline \multicolumn{10}{|l|}{ DON } \\
\hline ENV1 & 0.9 & 0.8 & $0.2^{*}$ & 0.9 & 0.7 & $0.2 * *$ & 0.8 & 0.8 & $0.0^{\mathrm{NS}}$ \\
\hline ENV2 & 3.3 & 3.2 & $0.1^{\mathrm{NS}}$ & 3.3 & 3.2 & $0.1^{\mathrm{NS}}$ & 3.1 & 3.2 & $0.1^{\mathrm{NS}}$ \\
\hline Difference & $3.3^{\mathrm{NS}}$ & $2.4^{\mathrm{NS}}$ & & $2.4^{\mathrm{NS}}$ & $2.5^{\mathrm{NS}}$ & & $2.3^{\mathrm{NS}}$ & $2.4^{\mathrm{NS}}$ & \\
\hline \multicolumn{10}{|l|}{ Net revenue } \\
\hline ENV1 & 804.74 & 835.56 & $30.82 * *$ & 819.12 & 845.77 & $26.64 * *$ & 841.79 & 832.44 & $9.34^{\mathrm{NS}}$ \\
\hline ENV2 & 536.71 & 561.80 & $25.09^{* *}$ & 549.87 & 569.59 & $19.72 * *$ & 565.94 & 559.73 & $6.21^{\mathrm{NS}}$ \\
\hline Difference & $268.03^{\mathrm{NS}}$ & $273.76^{\mathrm{NS}}$ & $\ldots$ & $269.25^{\mathrm{NS}}$ & $276.17^{\mathrm{NS}}$ & $\ldots$ & $275.85^{\mathrm{NS}}$ & $272.71^{\mathrm{NS}}$ & $\ldots$ \\
\hline
\end{tabular}

${ }^{a}$ Experiments included four fungicide treatments: 1, nontreated; 2, Feekes growth stage (FGS) 2 application at the four- to five-leaf crop growth stage using propiconazole (Tilt $3.6 \mathrm{EC}$ ) at $0.06 \mathrm{~kg}$ active ingredient (a.i.)/ha; 3, FGS 10.51 application at the early-anthesis crop growth stage using tebuconazole (Folicur 3.6 F) at $0.13 \mathrm{~kg}$ a.i./ha; and 4, FGS 2 application of propiconazole (Tilt $3.6 \mathrm{EC}$ ) at $0.06 \mathrm{~kg}$ a.i./ha followed by a FGS 10.51 application of tebuconazole (Folicur $3.6 \mathrm{~F}$ ) at $0.13 \mathrm{~kg}$ a.i./ha. All fungicide application treatments included $0.125 \%$ Induce, a nonionic surfactant. Differences (Diff.) calculated from estimate figures. Data rounding may have caused slight discrepancies. NS $=$ contrast differences not significant at $P \leq 0.05 ; *$ and $* *$ significant at the 0.05 and 0.001 levels, respectively.

${ }^{\mathrm{b}}$ Fusarium head blight (FHB) incidence, percent spikes 50/plot with at least one symptomatic spikelet; FHB severity, mean percent symptomatic spikelets from diseased spikes; FHB index, calculated using incidence and severity data (= [severity $\times$ incidence]/100); yield in $\mathrm{kg} / \mathrm{ha}$; test weight in $\mathrm{kg} / \mathrm{hl} ; \mathrm{protein}$ in percent; DON, deoxynivalenol in parts per million; net revenue, estimated using applicable commodity cash prices and an estimated cost for disease management strategy, expressed as \$/ha. Tests were conducted at five sites during 2004 (ENV1) where FHB development was low and three sites during 2005 (ENV2) where FHB development was moderate. 
The "noise" from leaf disease is largely unavoidable when experiments are situated within commercial production fields. To manage the potential of confounding injury from foliar and FHB diseases in each environment, we incorporated two fungicide application treatments at FGS 2. At first glance, the FGS 2 treatment does not appear to satisfactorily contribute to the objectives of this research. Data from these treatments enabled us to maintain the integrity of our FHB disease management study within an open agricultural production system. The purpose of the treatments was to prevent leaf diseases from becoming established in the lower plant canopy so that we could determine the extent of loss occurring from leaf diseases in our other two treatments. An early-season treatment of fungicide preserved agroecosystem environmental influences before and during the anthesis (FGS 10.51) crop growth stage to accommodate unaltered FHB disease development. We have included data from these treatments to demonstrate the effects leaf disease injury had on the economic outcomes of our experiment. We believe it was minimal.

Yield and net returns were significantly greater from five low-FHB-disease experiment locations (ENV1) compared with three moderate-disease experiment locations (ENV2) regardless of disease resistance levels of cultivars. Net revenues were significantly greater from MS cultivars compared with MR cultivars in low-FHBprevalence locations. Revenue differences were no longer significant between MS and MR cultivars when FHB disease symptoms were increased in ENV2. Yields of MR cultivars were not significantly different from those of MS cultivars at low-FHB-prevalence locations but differences were highly significant in favor of MR cultivars from moderate-FHB locations. Yields of both groups of cultivars were reduced significantly as FHB increased but the MS group had a 5.6\% greater drop in yield compared with the MR group. As a group, MR cultivars consistently produced grain with greater test weights and lower DON contents compared with MS cultivars within like environments. It is difficult to understand, then, how cultivars producing larger yields of higher-quality grain could return less revenue than their MS counterparts. The answer rests with Knudson. It is a cultivar that produces consistently large yields of low-protein grain, as shown in Table 3 . When grain grades and protein discounts are considered, the cultivar contributed enough low-protein grain to reduce revenues of the MR cultivar group. Future studies should include a larger number of cultivars to reduce the potential for skewing experiment results by a single cultivar.

Alsen, a cultivar recognized for its grain quality characteristics and high level of resistance to FHB, has been grown widely across North Dakota and Minnesota since its commercialization. We contrasted it to Walworth, a cultivar known less for quality grain. Compared with Walworth, Alsen had similar yields and showed fewer symptoms of FHB severity with a lower FHB index in ENV2. Alsen produced grain with significantly greater test weights and higher protein levels but, when a net revenue was calculated, higher grain quality did not significantly increase revenue of Alsen grain over that of lower-quality Walworth.

The two cultivars most susceptible to FHB were also considered. Compared with Reeder, Oxen showed fewer FHB incidence symptoms but had lower test weights in ENV2 when FHB was moderate. Regardless of environment, Oxen produced grain with less protein than Reeder, yet yields between the cultivars were not significantly different. Grain from Reeder contained more DON than Oxen in both environments. Revenues from Oxen were not different than Reeder in ENV1 but Oxen returned $13.8 \%$ greater revenues than Reeder in ENV2. Grain discounts on elevated levels of DON in ENV2 significantly upset the economic balance between the two cultivars. When low-quality grain is discounted for DON content, as in FHB epidemic years, grain quality issues come to the forefront of production concerns.

It is important that wheat producers know how cultivars respond to FHB if cultivars are to be grown in disease-prone environments. The shift in net returns from this example is evidence of the type of information most needed by extension specialists when educating small-grain crops stakeholders about sustainable disease-management practices.

Fungicide application resulted in significant economic benefits for MR as well as MS cultivars. In addition, fungicide resulted in fewer FHB incidence symptoms and, consequently, lower FHB indices for MR cultivars, whereas yields and test weights of MS cultivars were greater than the nontreated controls. However, differences in DON content did not result from fungicide application in either group. According to Mesterházy et al. (33), greater control of DON was achieved in European research when fungicide application was made on MR cultivars compared with MS cultivars. Our research did not detect response differences by cultivar resistance level. There is little agreement in the literature about the level of DON control one can expect following fungicide application. Paul et al. (41) estimated the mean percent control of DON resulting from tebuconazole application compared with nonfungicide treated controls from 101 independently conducted, inoculated field studies in the United States. Although their conclusions reported a mean control level at $21.6 \%$, results varied from $-200 \%$ to $100 \%$ control of the nontreated. Other researchers have reported variable results as well $(18,19,21,26,27,30,33,34,43)$. Mesterházy (32) suggests that the observed variability in DON control following fungicide application in inoculated trials may be caused, in part, by differing levels of pathogen aggressiveness. Similarly, researchers in the United States have suggested the possibility of population shifts within $F$. graminearum. Gale (16) states "...there are some reports that aggressiveness at a population level may be elevated in epidemic areas. This points to selection operating at a population level." Recent research has identified an emergent population of $F$. graminearum that has unique toxin production characteristics. The fungal population has been identified largely within the Red River Valley where severe and repeated epidemics have occurred since the early 1990s $(14,15)$. Producers have used tebuconazole to manage crop losses in wheat and barley caused from FHB for a number of years. At the time of these experiments, Minnesota and North Dakota producers relied on tebuconazole to manage FHB for a period of 9 and 10 years. Future studies should address whether selection pressure shifts have occurred within the pathogen population in the Red River Valley which may be preventing effective FHB management by fungicides.

MR cultivars consistently produced higher-quality grain compared with MS cultivars. Kernel quality was largely independent of fungicide treatment and was instead linked to quality characteristics of cultivars. These results indicate that cultivar selection, rather than fungicide treatment using tebuconazole, is the most effective tool to use for producing high-quality grain in disease-prone environments. Producers who value reliable quantities of high-quality grain, regardless of fungicide treatment, should grow cultivars having high resistance levels to FHB. Perhaps most importantly, the grain-processing industry could then expect higher-quality grain regardless of disease environment if MR cultivars are more widely grown compared with MS cultivars. This scenario is optimistic, however, when economic outcomes from fungicide application on FHBsusceptible cultivars are considered.

\section{ACKNOWLEDGMENTS}

This research was funded, in part, by the Minnesota Wheat Research and Promotion Council. We thank H. Michaels, research assistant; grower cooperators J. and C. Olsonawski, J. and M. Kukowski, R. and B. Swenson, B. and T. Hest, B. and K. Brendon, and T. and D. Jennen; Mid-Valley Grain Cooperative of Crookston; Y. Don of the University of Minnesota Mycotoxin Laboratory; BASF; Bayer CropScience; and Syngenta for their support.

\section{LITERATURE CITED}

1. Anderson, A. L. 1948. The development of Gibberella zeae headblight of wheat. Phytopathology 38:595-611.

2. Anderson, J. A., Linkert, G. L., Springer, C., and Wiersma, J. J. 2007. Hard Red Spring 
Wheat. Pages 43-48 in: Minnesota Varietal Trials Results. Minn. Agric. Exp. Stn. Pub. MP112. St. Paul, MN.

3. Anonymous. 1993. U.S. Food and Drug Administration, Center for Food Safety and Applied Nutrition. Guidance for Industry and FDA: letter to state agricultural directors, state feed control officials, and food, feed, and grain trade organizations. Online. http://www.cfsan. fda.gov/ dms/graingui.html.

4. Atanassov, Z., Nakamura, C., Mori, N., Kaneda, C., Kato, J., Jin, Y.-Z., Yoshizawa, T., and Murai, K. 1994. Mycotoxin production and pathogenicity of Fusarium species and wheat resistance to Fusarium head blight. Can. J. Bot. 72:161-167.

5. Bai, G., and Shaner, G. 1994. Scab of wheat: Prospects for control. Plant Dis. 78:760-766.

6. Christensen, C. M., Mirocha, C. J., and Meronuck, R. A. 1988. Molds and mycotoxins in feeds. Bull AG-FO-3538. Minn. Agric. Ext. Serv. St. Paul, MN

7. Christensen, J. J., and Kernkamp, H. C. H. 1936. Studies on the toxicity of blighted barley to swine. Minn. Agric. Exp. Stn. Bull. 113. St. Paul, MN.

8. Cowger, C., and Sutton, A. L. 2005. The southeastern U.S. Fusarium head blight epidemic of 2003. Online. Plant Health Progress doi:10.1094/PHP-2005-1026-01-RS.

9. Cutler, H. G. 1988. Trichothecenes and their role in the expression of plant disease. Pages 50-72 in: Biotechnology for Crop Protection. P. A. Hedin, J. J. Menn, and R. M. Hollingworth, eds. American Chemical Society, Washington, DC.

10. De Wolf, E. D., Madden, L. V., and Lipps, P. E. 2003. Risk assessment models for wheat Fusarium head blight epidemics based on withinseason weather data. Phytopathology 93:438435.

11. Dill-Macky, R., and Jones, R. K. 2000. The effect of previous crop residues and tillage on Fusarium head blight of wheat. Plant Dis. 84:71-76.

12. Gilbert, J., and Tekauz, A. 2000. Review: recent developments in research on Fusarium head blight of wheat in Canada. Can. J. Plant Pathol. 22:1-8.

13. Hagler, W. M. 1991. Potential for detoxification of mycotoxin-contaminated commodities. Pages 253-269 in: Pennington Center Nutrition Series: Mycotoxin, Cancer, and Health, Vol. a. G. A. Bray and D. H. Ryan, eds. Louisiana State University Press, Baton Rouge.

14. Gale, L. R., O'Leary, L. E., Bryant, J. D., Ochocki, G. E., Ward, T. J., and Kistler, H. C. 2005. Displacement of the native population of Fusarium graminearum in North Dakota and parts of Minnesota by a genetically divergent and more toxigenic population. 2005. Page 158 in: Proc. Natl. Fusarium Head Blight Forum. S. M. Canty, J. Lewis, L. Siler, and R. W. Ward, eds. Michigan State University, East Lansing.

15. Gale, L. R., Ward, T. J., Blamas, V., and Kistler, H. C. 2007 Population subdivision of Fusarium graminearum sensu stricto in the upper Midwestern United States. Phytopathology 97:1434-1439.

16. Gale, R. G. 2003. Population biology of Fusarium species causing head blight of grain crops. Pages 120-143 in: Fusarium Head Blight of Wheat and Barley. K. J. Leonard and W. R. Bushnell, eds. American Phytopathological Society, St. Paul, MN.

17. Hollingsworth, C. R., Mewes, J. J., Motteberg, C. D., and Thompson, W. G. 2006. Predictive accuracy of a Fusarium head blight epidemic risk forecasting system deployed in Minnesota. Online. Plant Health Progress doi:10.1094/ PHP-2006-1031-01-RS

18. Hollingsworth, C. R., Motteberg, C. D., and Thompson, W. G. 2005. 2005 FHB Uniform fungicide trial on hard red spring wheat in Minnesota. Pages 200-202 in: Proc. Natl. Fusarium Head Blight Forum. S. M. Canty, J. Lewis, L. Siler, and R. W. Ward, eds. Michigan State University, East Lansing.

19. Homdork, S., Fehrmann, H., and Beck, R. 2000. Effects of field application of tebuconazole on yield, yield components and the mycotoxin content of Fusarium-infected wheat grain. J. Phytopathol. 148:1-6.

20. Johnson, D. D., Wilson, W. W., and Diersen, M. 1995. Quality uncertainty and grain merchandising risk: Vomitoxin in spring wheat. N.D. Agric. Exp. Stn. Rep. No. 333.

21. Jones, R. K. 2000. Assessments of Fusarium head blight of wheat and barley in response to fungicide treatment. Plant Dis. 84:1021-1030.

22. Jones, R. K., and Mirocha, C. J. 1999. Quality parameters in small grains from Minnesota affected by Fusarium head blight. Plant Dis. 83:506-511.

23. Littell, R. C., Milliken, G. A., Stroup, W. W., and Wolfinger, R. D. 1996. Pages 1-29 in: SAS for Mixed Models. SAS Press, Cary, NC.

24. Littell, R. C., Milliken, G. A., Stroup, W. W., Wolfinger, R. D., and Schabenberger, O. 2006. Pages 1-242 in: SAS for Mixed Models, 2nd ed. SAS Press, Cary, NC.

25. MacInnes J., and Fogelman, R. 1923. Wheat scab in Minnesota. Minn. Ext. Serv. Tech Bull. 18. St. Paul, MN

26. Martin, R. A., and Johnston, H. W. 1982. Effects and control of Fusarium diseases of cereal grains in the Atlantic Provinces. Can. J. Plant Pathol. 4:210-216.

27. Matthies, A., and Buchenauer, H. 1999. Effect of tebuconazole (Folicur) and prochloraz (Sportak) treatments on Fusarium head scab development, yield and deoxynivalenol (DON) content in grains of wheat following artificial inoculation with Fusarium culmorum. J. Plant Dis. Prot. 107:33-52.

28. McMullen, M. 2003. Impacts of Fusarium head blight on the North American agricultural community: the power of one disease to catapult change. Pages 484-503 in: Fusarium Head Blight of Wheat and Barley. K. J. Leonard and W. R. Bushnell, eds. American Phytopathological Society, St. Paul, MN.

29. McMullen, M., Jones, R., and Gallenberg, D. 1997. Scab of wheat and barley: a re-emerging disease of devastating impact. Plant Dis. 81:1340-1348.

30. McMullen, M., Lukach, J., McKay, K., and Schatz, B. 2005. Wheat uniform fungicide trials, ND, 2005. Pages 218-220 in: Proc. Natl. Fusarium Head Blight Forum. S. M. Canty, J. Lewis, L. Siler, and R. W. Ward, eds. Michigan State University, East Lansing.

31. Mesterházy, Á. 1995. Types and components of resistance to Fusarium head blight of wheat. Plant Breed. 114:377-386.

32. Mesterházy, Á. 2003. Control of Fusarium head blight of wheat by fungicides. Pages 363380 in: Fusarium Head Blight of Wheat and Barley. K. J. Leonard and W. R. Bushnell, eds. American Phytopathological Society, St. Paul, $\mathrm{MN}$.

33. Mesterházy, Á., Bartók, T., and Lamper, C. 2003. Influence of wheat cultivar, species of Fusarium, and isolate aggressiveness on the efficacy of fungicides for control of Fusarium head blight. Plant Dis. 87:1107-1115.

34. Milus, E. A., and Parson, C. E. 1994. Evaluation of foliar fungicides for controlling Fusarium head blight of wheat. Plant Dis. 78:697699.

35. Mirocha, C. J., Kolaczkowski, E., Xie, W., Yu, H., and Helen, H. 1998. Analysis of deoxynivalenol and its derivative (batch and single kernel) using gas chromatography/mass spectrometry. J. Agric. Food Chem. 46:1424-1428.

36. Mirocha, C. J., Xie, W., and Filho, E. R. 2003. Chemistry and detection of Fusarium my- cotoxins. Pages 144-164 in: Fusarium Head Blight of Wheat and Barley. K. L. Leonard and W. R. Bushnell, eds. American Phytopathological Society, St. Paul, MN

37. Nganje, W. E., Bangsund, D. A., Leistritz, F. L., Wilson, W. W., and Tiapo, N. M. 2004. Regional economic impacts of Fusarium head blight in wheat and barley. Rev. Agric. Econ. 26:332-347.

38. Özberk, İ., Kılıç, H., Ath, A., Özberk, F., and Karl1. B. 2006. Selection of wheat based on economic returns per unit area. Euphytica 152:235-245.

39. Parry, D. W., Jenkinson, P., and McLeod, L. 1995. Fusarium ear blight (scab) in small grain cereals-a review. Plant Pathol. 44:207-238.

40. Paul, P. A., El-Allaf, S. M., Lipps, P. E., and Madden, L. V. 2006. Relationships between incidence and severity of Fusarium head blight on winter wheat in Ohio. Phytopathology 95:1049-1060.

41. Paul, P. A., Lipps, P. E., Hershman, D. E., McMullen, M. P., Draper, M. A., and Madden, L. V. 2007. A quantitative review of tebuconazole effect on Fusarium head blight and deoxynivalenol content in wheat. Phytopathology 97:211-220.

42. Paul, P. A., Lipps, P. E., and Madden, L. V. 2005. Relationship between visual estimates of Fusarium head blight intensity and deoxynivalenol accumulation in harvested wheat grain: A meta-analysis. Phytopathology 95:1225-1236.

43. Ramirez, M. L., Chulze, S., and Magan, N. 2003. Impact of environmental factors and fungicides on growth and deoxynivalenol production by Fusarium graminearum isolates from Argentinean wheat. Crop Prot. 23:117125.

44. Schabenberger, O., and Pierce, F. J. 2002. Pages 474-504 in: Contemporary Statistical Models for the Plant and Soil Sciences. CRC Press, Boca Raton, FL.

45. Scott, P. M. 1990. Trichothecenes in grains. Cereal Foods World 35:661-666

46. Shaner, G. 2003. Epidemiology of Fusarium head blight of small grain cereals in North America. Pages 84-119 in: Fusarium Head Blight of Wheat and Barley. K. J. Leonard and W. R. Bushnell, eds. American Phytopathological Society, St. Paul, MN

47. Stack. R. 2003. History of Fusarium head blight with emphasis on North America. Pages 1-34 in: Fusarium Head Blight of Wheat and Barley. K. J. Leonard and W. R. Bushnell, eds. American Phytopathological Society, St. Paul, $\mathrm{MN}$.

48. Stack R. W. 2000. Return of an old problem: Fusarium head blight of small grains. Plant Health Progress doi:10.1094/PHP-2000-062201-RV.

49. Stack, R. W., and McMullen, M. P. 1995. A visual scale to estimate severity of Fusarium head blight in wheat. N. D. State Univ. Agric. Exp. Stn. Bull. 1095. Fargo, ND.

50. Steffenson, B. J. 2003. Fusarium head blight of barley: Impact, epidemics, management, and strategies for identifying and utilizing genetic resistance. Pages 242-295 in: Fusarium Head Blight of Wheat and Barley. K. J. Leonard and W. R. Bushnell, eds. American Phytopathological Society, St. Paul, MN.

51. Vesonder, R. F., Ciegler, A., and Jensen, A. J. 1973. Isolation of the emetic principles from Fusarium graminearum-infected corn. Appl. Microbiol. 26:1008-1010.

52. Wiersma, J. J., Ransom, J. K., and Hofman, V. 2005. Planting. Pages 28-33 in: The Small Grains Field Guide. J. J. Wiersma and J. K Ransom, eds. Univ. Minn. Ext. Serv. Publ. 07488-S

53. Windels, C. E. 2000. Economic and social impacts of Fusarium head blight: Changing farms and rural communities in the northern Great Plains. Phytopathology 90:17-21. 